\title{
TITLE:
}

\section{Cell Cycle in the Primitive Streak and the Notochord of Early Chick Embryos(Abstract_要旨)}

$\operatorname{AUTHOR(S):~}$

Ozato, Kenjiro

CITATION:

Ozato, Kenjiro. Cell Cycle in the Primitive Streak and the Notochord of Early Chick Embryos. 京都大学, 1968, 理学博士

\section{ISSUE DATE:}

1968-07-23

URL:

http://hdl.handle.net/2433/212926

RIGHT: 


\section{【 26 】}

氏 名

学位 $の$ 種 類

尾里 建 二郎

学位記番号

学博士

学位授与の日付

理 博 第 140 号

学位授与の要件

昭 和 43 年 7 月 23 日

研究科. 専攻

学位規則第 5 条第 1 項該当

学位論文題目

理学研究科動物学専攻

\section{Cell Cycle in the Primitive Streak and the Notochord of Early Chick Embryos}

(ニワトリ初期胚の原条と脊索に打ける細胞周期)

論文調査委員教 主授查岡田節人 教授加藤幹太教授 竹内郁夫

\section{論 文内，容の要 旨}

申請者, 尾里建二郎は，その主論文において、ニワトリ初期胚の囊胚形成期に著しい造形運動を行なう 組織群の細胞について, その細胞サイクルを研究している。現在, 細胞のサイクル,すなわち, DNA 合 成という細胞の繰り返えしている過程を研究するには, 細胞に, DNA の前駆物質であるチミジンをアイ ソトープラベルしたあの， ${ }^{3} \mathrm{H}$ - チミジンをあたえ，てのような資料を組織切片としてオートラジオグラ フィーとして検する方法が，あまねく用いられる。ての方法をニワトリ初期胚について適用するため， ワトリ初期胚をガラス器内に培羪して発生させ，2２4時閒の間のいろいろな時間だけ ${ }^{3} \mathrm{H}$ チミジンを 与えて, オートラジオグラフィーとして観察した。刘象とする囊胚形成期では細胞群の著しい移動があ り, 複雑な形態を呈しているので，連続切片を作製し，胚の原条に沿って前後に，ラベルされた核数と， 分裂像をもった核数を数えることによって研究を行なった。

てのような観察によって得られた知見は次の如くである。

1）肧の原条にそってラベル指数（ ${ }^{3} \mathrm{H}$ ーチミジンでラベルされた核数/一定面積内の総核数）は，その 中央部で最高であり，前端で最低となる。分裂指数（分裂像をむった核数/総核数）は，逆の傾向を示し ており，原条中央部で最低で，前端部で高い。

2）ラベル指数は，原条前端で最低であるが，とこで細胞が陥入すると，前方へ向かって逐次増加の傾 向を示す。分裂指数の分布はちょうど逆の傾向を示し，ラベル指数の高まった部域で最低となる。

てれらの知見は, 睬卵15時間位の頭突起期から,すでに体節がつくられている時間の胚までについて, 原則的には一致している。また, アイソトープ投与時期, 投与アイソトープの活性をいるいろ变えるとと によって，繰り返えし確認するのに成功しえたのである。

申請者は，とのような知見にもとづいて，原条をなす細胞には，その細胞サイクルにおいてかなりの同 時性が存在する，という注目すべき結論をえた。また，原条前端から陷入する細胞は，多くがM一期にあ り, 陥入後, 前方に移動するにつれて S一期に達するが, やがててのような同時性は失われてゆくと考察 


\section{するのである。}

参考論文のうち，(3)は，主論文の予備的結果の速報である。(1)は，主論文と全く同じ方法を駆使して， ニワトリ泼における肧誘導の誘導原組織たる脊索と, その反応系である神経組織との細胞周期を比較して いる。その結果, 頭突起期においては, 両組織で細胞サイクルはかなりよく一致しているととを示した。 参考論文(2)は，内容の全く異なるものであって，ニワトリ腎臟ミクロゾームの分子構成を免疫学的方法之 組織化学的方法とを併用して，抗原として同定しうる分子のどれだけが酵素活性をもったものであるかを 知ろうとしだのである。ミミロゾームの構成抗原分子のうち，デオキシコール酸で可溶化されるものの 中には，エステラーゼ活性をもつもの数個，アルカリ性フォスファターゼ活性をあつあの数個のあること を示している。

\section{論 交審查の結果の要旨}

動物の初期発生の開始時期においては，細胞は同時的に分裂するので，細胞数は，2，4，8，16… ‥個と規則正しく増加する。また，乙の時期では，細胞分裂は速やかに起てっているので，結局，短時日 の間に受精卵という単一細胞は, 多数の細胞から構成される肧へと発生する。やがて胚の各部で, 細胞群 が著しい移動，運動を行なうことになるが，てれを襄胚形成期という。囊胚形成期における細胞群の動き が, 将来の発生, 形態形成に極めて重要な意義をむつととは古くから知られているととろであり, 数多く の研究がなされている。しかし, それらの殆んぞが, 形態学的, あるいは実験形態学的な研究であって, 申請者の行なったような細胞生物学的な方法による研究は皆無に等しい状勢であった。従って靁胚形成之 いう過程が発生学的に極めて重要な意義のあることが知られていてす, その個々の細胞について知られて いるとてろが殆んどなかったのである。申請者は，その主論文をなす研究において，囊胚形成の中心をな す原条の細胞の細胞サイクルをニワトリ胚においてかなり明らかにするととに成功した。それによると， 原条の先端部をなし，宿入して中胚葉の形成を行なわんとする細胞には，細胞サイクルに同時性があると いう。すでに述べたように，細胞サイクルの同時性は，発生のごくごく初期の，卵割期という時期の細胞 に限られた性質とされてきたから，てれは発生学上注目すべき発見である。とのような同時性の結果とし て, 原条先端で陥入する細胞周期のフェーズはかなり一定していて, 多くがM期と呼ばれる時期にあり, 陥入することによって，やがて S 期に移る。陥入した細胞は前方に向かって移動しつつ春索を形成する が，前方に進むにしたがって細胞周期の同時性は漸次失われてゆく。

申請者は, ニワトリ初期胚の体外培養したあのについて, DNA 前駆物質である ${ }^{3} \mathrm{H}$ チミジンをあた え,オートラジオグラフィーによってラベルされた細胞と，細胞分裂像とを胚の各部域について詳細に数 えることによって，上記の知見を得ることに成功した。てれらの知見の発生学的な考察については，今後 の研究にまたねばならないとてろであるが，現在まで囊胚形成中の細胞についての，乙のような細胞生物 学的知見が皆無に近く，大いに期待されていたととろであるから，申請者の貢献は重要な意義のあるあの といえる。観察む十分に詳細であって，申請者の発見は理学博士の学位を受けるにふさわしいむのと考え られる。

参考論文(2)，(3)は，主論文と直接，間接に関係したあのであるが，参考論文(1)は，全く趣きを異にした 
あのである。この論文で申請者は, ニワトリ腎臟ミクロゾームの構成分子を免疫学的方法と組織化学的方 法とを併用して研究し，抗原しして検出される分子のいくらかがアルカリ性フォスファターゼ，いくらか がエステラーゼの活性をもったととを示しており，発表当時，あまねく注目を集めたもので，申請者の研 究能力の多面性がよく示されている。

よって，本論文は理学博士の学位論文として価值があるものと認める。 